\title{
A Comparison of Sampling Sites, Digesta and Microbial Markers, and Microbial References for Assessing the Postruminal Supply of Nutrients in Dairy Cows ${ }^{1}$
}

\author{
I. R. Ipharraguerre,${ }^{\star 2,3}$ S. M. Reynal,$\dagger^{4}$ M. Liñeiro, ${ }^{* 5}$ G. A. Broderick, $\ddagger$ and J. H. Clark ${ }^{\star}$ \\ *Department of Animal Sciences, University of Illinois, Urbana 61801 \\ †Department of Dairy Science, University of Wisconsin, Madison 53706 \\ $\ddagger$ Agricultural Research Service, USDA, US Dairy Forage Research Center, Madison 53706
}

\begin{abstract}
This study evaluated the impact of some methodological factors on the flows of nutrients at the omasal canal and duodenum of dairy cows fed corn-based diets. Three ruminally and duodenally cannulated cows were assigned to an incomplete $4 \times 4$ Latin square with four 14 $\mathrm{d}$ periods and fed diets formulated to contain different amounts and ruminal degradabilities of crude protein. Samples from the omasal canal and duodenum were obtained and processed according to methodologies routinely used in our laboratories and elsewhere. Methodological factors that were evaluated included microbial references and markers, digesta markers, and sampling sites (techniques). Considerable variation was found for the compositions of microbial references and their impact on the intestinal supply of microbial nonammonia nitrogen. Likewise, it appears that variation in measuring the ruminal outflow of nitrogen fractions of microbial and dietary origin could be reduced by using ${ }^{15} \mathrm{~N}$ rather than purines as microbial markers. Sampling from the omasum and duodenum resulted in differences for ruminal outflow and site of digestion as well as digestibility of some nutrients, particularly nitrogen fractions and starch. A sizable portion of this variation was associated with deviations from the assumed ideal behavior of digesta markers and collection of samples that were unrepresentative of true digesta. Collectively, outcomes from this study indicate that more research
\end{abstract}

Received March 3, 2006.

Accepted November 7, 2006.

${ }^{1}$ Mention of any trademark or proprietary product in this paper does not constitute a guarantee or warranty of the product by the USDA or the ARS and does not imply its approval to the exclusion of other products that also may be suitable.

${ }^{2}$ Corresponding author: Ignacio.Ipharraguerre@lucta.es

${ }^{3}$ Current address: Lucta S. A., P.O. Box 1112, Barcelona 08080, Spain.

${ }^{4}$ Current address: US Dairy Forage Research Center, Madison, WI 53706.

${ }^{5}$ Current address: Facultad de Agronomía, Universidad de Buenos Aires, Argentina. will be required to determine the accuracy of nutrient flows and the agreement between measurements at the omasal canal and duodenum when dairy cows are fed a variety of diets under different feeding systems. Therefore, caution is recommended when extrapolating or interpreting the underlying biology of published results as well as the results of their application (e.g., model parameters and predictions).

Key words: dairy cow, nutrient flow, omasum, duodenum

\section{INTRODUCTION}

Over the years, significant efforts have been made to understand and quantify the intestinal supply of nutrients in dairy cows. A salient characteristic of these estimates is their highly variable nature, which arises from the technical challenges encountered when measuring the flow of nutrients through the digestive tract and the numerous factors that modulate this process. This limitation hampers our ability to predict precisely and accurately the postruminal flow of nutrients in dairy cows.

Surgical cannulation of the gastrointestinal tract is required in ruminant animals to assess the kinetics of nutrient digestion in the rumen and the passage of nutrients to the absorption sites in the intestines. Although the commonly used simple-T cannula offers fewer postsurgical complications than the reentrant cannula, digesta samples may not be representative of digesta leaving the rumen (Faichney, 1993; Harmon and Richards, 1997). Because digesta flow at the duodenum is tubular in nature, the use of closed-T duodenal cannulas with complete diversion of the flow and frequent sampling throughout the day may result in collection of representative samples (Firkins et al., 1998). However, this cannulation surgery is invasive, maintenance of cannulated animals is laborious, and the longevity of experimental animals often is compromised.

An alternative involves sampling digesta that flow out of the rumen into the omasal canal. The omasal 
sampling technique developed by Punia et al. (1989) and modified by Huhtanen et al. (1997) and Ahvenjärvi et al. (2000) can be used for such a purpose, using animals fitted with only ruminal cannulas. Because ruminal cannulation is less invasive and expensive than duodenal cannulation, more experimental animals can be used to increase the statistical power and detect differences among treatments that otherwise would be declared insignificant (i.e., reducing type II error). Compared with duodenal sampling, collection of omasal samples avoids limitations imposed by abomasal digestion and contamination of digesta with abomasal secretions. However, omasal sampling is more labor intensive and requires the use of more sophisticated equipment. More important, because samples taken from the omasal canal are not representative of true digesta, a multiple marker system must be used to mathematically reconstitute digesta samples, increasing the probability of compounding analytical errors.

Omasal flows of some $\mathrm{N}$ and fiber fractions have been shown to be representative of duodenal flows (Ahvenjärvi et al., 2000) under feeding conditions (high forage, small grain-based diets) that differ substantially from those usually found in the United States and other countries (corn-based diets) in terms of the physical characteristics of both the diets fed and the digesta leaving the rumen. Data from experiments comparing flow of nutrients determined at the omasal canal and the duodenum of dairy cows fed corn-based diets that contained different sources of supplemental CP are not available. Consequently, the objectives of the present trial were to identify, compare, and discuss major limitations associated with the use of the omasal canal and duodenal sampling techniques for measuring nutrient passage in dairy cows fed corn-based diets that contained different sources of $\mathrm{CP}$, and to evaluate the impact of different digesta and microbial markers as well as microbial references on the estimation of nutrient flows at these sites of the digestive tract.

\section{MATERIALS AND METHODS}

\section{Animal Management, Experimental Design, and Diets}

Three lactating Holstein cows in their fourth lactation, averaging $154( \pm 92) \mathrm{DIM}$ at the beginning of the trial and previously fitted with ruminal and duodenal cannulas according to procedures approved by the University of Illinois Laboratory Animal Care Advisory Committee, were used in this experiment. The ruminal cannulas were constructed of soft plastic (Bar Diamond, Parma, ID) and measured $10.2 \mathrm{~cm}$ in diameter. The duodenal cannulas were of a closed T-shaped design made of stainless steel (Berzins Vet Laboratory Ltd.,
Table 1. Ingredient and chemical composition of $\operatorname{diets}^{1}$ (DM basis)

\begin{tabular}{lcccc}
\hline Item & Urea & SSBM & XSBM & CGM \\
\hline Ingredient & & & & \\
Alfalfa silage, \% & 25.0 & 25.0 & 25.0 & 25.0 \\
Corn silage, \% & 35.0 & 35.0 & 35.0 & 35.0 \\
Ground shelled corn, \% & 34.8 & 32.1 & 32.7 & 28.6 \\
Urea, \% & 2.3 & - & - & - \\
Solvent-extracted SBM, ${ }^{2} \%$ & - & 5.2 & - & - \\
Xylose-treated SBM, ${ }^{3} \%$ & - & - & 4.6 & - \\
Corn gluten meal, \% & - & - & - & 8.5 \\
Sodium chloride, \% & 0.14 & 0.14 & 0.14 & 0.14 \\
Sodium bicarbonate, \% & 1.0 & 1.0 & 1.0 & 1.0 \\
Dicalcium phosphate, \% & 0.60 & 0.41 & 0.42 & 0.45 \\
Limestone, \% & 0.60 & 0.60 & 0.65 & 0.65 \\
Sodium sulfate, \% & 0.14 & 0.14 & 0.14 & 0.14 \\
Magnesium oxide, \% & 0.14 & 0.14 & 0.14 & 0.18 \\
Mineral and vitamin mix, ${ }^{4} \%$ & 0.25 & 0.25 & 0.25 & 0.25 \\
Chemical composition & & & & \\
DM, \% & 50.4 & 50.4 & 50.7 & 49.6 \\
CP, \% of DM & 19.7 & 15.8 & 15.3 & 18.2 \\
NDF, \% of DM & 31.8 & 28.6 & 30.0 & 28.1 \\
ADF, \% of DM & 20.0 & 17.8 & 17.5 & 17.6 \\
Starch, \% of DM & 28.1 & 28.1 & 27.2 & 26.1 \\
NFC, \% of DM & 41.2 & 44.8 & 45.5 & 42.5 \\
NE,${ }^{5}$ Mcal/kg & 1.57 & 1.59 & 1.56 & 1.58 \\
\hline
\end{tabular}

${ }^{1} \mathrm{SSBM}=$ solvent-extracted soybean meal; XSBM = xylose-treated soybean meal; CGM = corn gluten meal.

${ }^{2}$ Soybean meal, $48 \% \mathrm{CP}$.

${ }^{3}$ Soypass; Ligno Tech USA, Inc. (Rothschild, WI).

${ }^{4}$ Contained $5.0 \% \mathrm{Mg}, 7.5 \% \mathrm{~K}, 10.0 \% \mathrm{~S}, 3.0 \% \mathrm{Zn}, 3.0 \% \mathrm{Mn}, 2.0 \%$ $\mathrm{Fe}, 0.5 \% \mathrm{Cu}, 0.025 \% \mathrm{I}, 0.015 \% \mathrm{Se}, 0.004 \% \mathrm{Co}, 2,200 \mathrm{IU}$ of vitamin $\mathrm{A} / \mathrm{g}, 660 \mathrm{IU}$ of vitamin $\mathrm{D}_{3} / \mathrm{g}$, and $8 \mathrm{IU}$ of vitamin $\mathrm{E} / \mathrm{g}$.

${ }^{5}$ Calculated using the NRC model (2001) and assuming an intake of 4 times maintenance.

Edmonton, Alberta, Canada). They were placed proximal to the common bile and pancreatic duct, about 10 $\mathrm{cm}$ distal to the pylorus.

Cows were housed in tie stalls bedded with straw and had free access to water throughout the trial. Cows were allowed to exercise in a dry lot from 0800 to 0900 $\mathrm{h}$ and were milked daily at 0500 and $1700 \mathrm{~h}$. Cows were injected with bST (500 mg of Posilac; Monsanto, St. Louis, MO) beginning on $\mathrm{d} 7$ of the trial and thereafter at 14-d intervals until the end of the trial. Cows were fed a TMR ad libitum twice daily as follows: two-thirds of the diet was fed immediately after mixing the feeds at $1730 \mathrm{~h}$, and the remaining TMR was held at $5^{\circ} \mathrm{C}$ and fed the next day at $0500 \mathrm{~h}$. Orts were collected and weighed once daily at $1700 \mathrm{~h}$, and the feeding rate was adjusted daily to yield orts of about $10 \%$ of intake.

The experimental design was an incomplete $4 \times 4$ Latin square with 4 treatments, 4 periods, and 3 cows. Each experimental period lasted $14 \mathrm{~d}$ and consisted of an 8-d adaptation period and a 6-d sample collection period. Each cow was randomly assigned to one of 3 treatment sequences in which a treatment never followed any other treatment more than once. Four dietary treatments (Table 1) that contained different 
sources and degradabilities of protein were fed to the cows to compare sampling techniques at the omasum and duodendum. Details and discussion of diet and individual treatment effects on the ruminal outflow of $\mathrm{N}$ fractions are provided in the companion paper by Reynal et al. (2007). Diets were adjusted weekly to reflect changes in DM of forages and concentrate mixtures by drying weekly composites of each ingredient overnight in an oven at $105^{\circ} \mathrm{C}$.

\section{Sampling, Measurements, and Analyses}

Feed and Ingredients. Feed offered and refused was measured and recorded daily. Samples of orts, silages, concentrates, and TMR were collected during the last $7 \mathrm{~d}$ of each period and stored at $-20^{\circ} \mathrm{C}$ until the time of processing. At the end of each period, samples were thawed and composited on an equal weight basis, and a representative subsample was dried at $55^{\circ} \mathrm{C}$ for $72 \mathrm{~h}$. Dried subsamples were sequentially ground through 2- and 1-mm screens using a Wiley mill (Arthur H. Thomas, Philadelphia, PA) and analyzed for DM at $105^{\circ} \mathrm{C}$; ash and $\mathrm{OM}$ (AOAC, 1990); total $\mathrm{N}$ using a combustion assay (Leco FP-2000 N Analyzer; Leco Instruments, Inc., St. Joseph, MI); starch (Kartchner and Theurer, 1981); and sequentially for NDF and ADF using heat-stable $\alpha$-amylase and $\mathrm{Na}_{2} \mathrm{SO}_{3}$ (Hintz et al., 1995).

Ruminal Fluid. Samples of ruminal fluid were collected at 1800,1900,2000, and $2200 \mathrm{~h}$ on d 8 and at $0100,0500,0600,0700,0800,1000$, and $1300 \mathrm{~h}$ on $\mathrm{d} 9$ of each period. Ruminal fluid samples were collected from multiple sites in the rumen, and $\mathrm{pH}$ of the ruminal fluid was measured immediately by glass electrode.

Duodenal Digesta. Samples of duodenal digesta were collected 4 times daily at 2 -h intervals on d 12 , 13 , and 14 of each period such that the samples taken represented a 24 -h feeding cycle over $3 \mathrm{~d}$. The sampling time was adjusted ahead $2 \mathrm{~h}$ daily so that a sample was obtained for each 2 -h interval of the day. Following removal of the cap of the duodenal cannula, accumulated digesta were discarded and, when the flow appeared normal, $500 \mathrm{~mL}$ of duodenal contents were collected. The $\mathrm{pH}$ of duodenal digesta was measured immediately by glass electrode. The volume of sample collected represented less than $2 \%$ of the estimated passage of digesta to the duodenum during the $3 \mathrm{~d}$ of collection. Samples were pooled by cow and stored at $-20^{\circ} \mathrm{C}$ until analysis. Duodenal samples were thawed and homogenized for 5 min using a propeller-type mixer (Jumbo mixer, model 40; Fisher Scientific International Inc., Hampton, NH) set at high speed. During continuous stirring, a representative subsample $(1,000 \mathrm{~mL})$ of digesta was collected by vacuum. Samples were then poured into shallow pans, lyophilized, ground through a 1-mm screen, and analyzed for DM, OM, total N, starch, ADF, and NDF as described above. Extracts for ammonia analysis by flow injection (Dual-Channel QuikChem 8000 FIA; Lachat Instruments, Milwaukee, WI) were prepared by adding $10 \mathrm{~mL}$ of $\mathrm{pH} 2.2 \mathrm{Na}$ citrate buffer to $0.5 \mathrm{~g}$ of sample; after mixing, samples were held at $39^{\circ} \mathrm{C}$ for $30 \mathrm{~min}$ and centrifuged $(15,000$ $\times g, 4^{\circ} \mathrm{C}, 15 \mathrm{~min}$ ), and the supernatant was stored at $-20^{\circ} \mathrm{C}$ until analysis.

Omasal Digesta. Digesta flow leaving the rumen was quantified using the omasal sampling technique developed by Huhtanen et al. (1997) and modified by Ahvenjärvi et al. (2000). Spot samples were collected from the omasal canal of each cow immediately after collecting the duodenal samples. Each omasal spot sample was divided into 3 subsamples of 125,200 , and 30 $\mathrm{mL}$, respectively. The $125-\mathrm{mL}$ subsamples were stored in an ice bath as they were collected, pooled over the 4 sampling times to yield one 500-mL composite from each cow on each sampling day, and processed later that day to isolate bacteria. The $200-\mathrm{mL}$ subsamples were stored at $-20^{\circ} \mathrm{C}$ as they were collected and pooled over the 12 sampling times to yield one 2.4 -L omasal composite from each cow in each period. The $30-\mathrm{mL}$ subsamples were used to study the effects of individual treatments on the flow of soluble $\mathrm{N}$ fractions at the omasal canal (Reynal et al., 2007).

The 2.4-L pooled omasal composites were thawed at room temperature and separated into 3 digesta phases as follows. Samples were squeezed through 1 layer of cheesecloth, and the solids retained were defined as the large-particle phase (LP). The filtrate was centrifuged at $1,000 \times g\left(5^{\circ} \mathrm{C}, 5 \mathrm{~min}\right)$, and the supernatant was carefully decanted from the pellet. The supernatant was defined as the fluid phase (FP) and the pellet as the small-particle phase (SP). These separated phases were frozen, freeze-dried, and then ground through a 1-mm screen for later analysis.

Concentrations of $\mathrm{Co}, \mathrm{Yb}$, and indigestible $\mathrm{NDF}$ (INDF) in LP and SP, and of $\mathrm{Co}$ and $\mathrm{Yb}$ in $\mathrm{FP}$ were used to mix DM from freeze-dried FP, SP, and LP in the correct proportions to reconstitute the omasal true digesta (OTD) flowing out of the rumen based on the triple-marker method of France and Siddons (1986). Aliquots of the SP and LP were mixed in the correct proportions based on the markers to yield a 2-g sample that was ground through a $0.5-\mathrm{mm}$ screen with an Udy Cyclone sample mill (Udy Corporation, Fort Collins, CO) and defined as small plus large particles (SP + LP). The OTD samples were analyzed for DM, OM, ammonia, total $\mathrm{N}$, starch, $\mathrm{ADF}$, and NDF as described above. 
Digesta Markers. Cobalt-EDTA (Uden et al., 1980), $\mathrm{YbCl}_{3}$ (modified from Siddons et al., 1985), INDF (Huhtanen et al., 1994), and $\mathrm{Cr}_{2} \mathrm{O}_{3}$ were used as markers to assess the postruminal flow of digesta. Cobalt-EDTA and $\mathrm{YbCl}_{3}$ were dissolved in distilled water and infused into the rumen at constant daily rates of $2.6 \mathrm{~g}$ of Co and $2.2 \mathrm{~g} \mathrm{Yb}$. Markers were infused for $150 \mathrm{~h}$ from $\mathrm{d} 8$ at $0900 \mathrm{~h}$ to $\mathrm{d} 14$ at $1500 \mathrm{~h}$ using a syringe pump (model no. 33; Harvard Apparatus, Inc., Holliston, MA). The $\mathrm{YbCl}_{3}$ was prepared by adding $230 \mathrm{~g}$ of $\mathrm{Yb}_{2} \mathrm{O}_{3}$ to 200 $\mathrm{mL}$ of distilled water plus $320 \mathrm{~mL}$ of concentrated $\mathrm{HCl}$, heating, and stirring until the solution was clear, then diluting to $5 \mathrm{~L}$ with distilled water. Samples of LP, SP, $\mathrm{FP}$, and infused markers were analyzed for $\mathrm{Co}$ and $\mathrm{Yb}$ as described by Reynal and Broderick (2005).

Gelatin capsules containing $10 \mathrm{~g}$ of $\mathrm{Cr}_{2} \mathrm{O}_{3}$ were administered via the ruminal cannula at 0600 and 1800 $\mathrm{h}$ during the last $10 \mathrm{~d}$ of each period. The concentration of $\mathrm{Cr}$ in duodenal samples was quantified by atomic absorption spectroscopy (air plus acetylene flame; PerkinElmer, Norwalk, CT) after preparation of samples by the procedure of Williams et al. (1962). Indigestible NDF was determined in LP, SP, and TMR samples (but not in FP; Ahvenjärvi et al., 2000), as described by Reynal and Broderick (2005).

Microbial Markers and References. Total purines and ${ }^{15} \mathrm{~N}$ were used to measure microbial NAN flows at the omasal canal and duodenum. Before starting the infusion of markers, a sample of whole ruminal contents was taken from each cow to determine the ${ }^{15} \mathrm{~N}$ background $\left({ }^{15} \mathbf{N B}\right)$. In the solution containing Co-EDTA and $\mathrm{YbCl}_{3}, 10 \%$ atom excess ${ }^{15} \mathrm{NH}_{4} \mathrm{SO}_{4}$ was dissolved and infused into the rumen at a constant daily rate (182 $\mathrm{mg}$ of ${ }^{15} \mathrm{~N}$ ) according to the procedure described for the infusion of digesta markers.

At the end of each sampling day, the 500-mL omasal composites were separated into phases that were equivalent to the FP and the SP + LP to isolate, respectively, fluid-associated bacteria (FAB) and particle-associated bacteria (PAB). Omasal composites were squeezed through 1 layer of cheesecloth; solids retained on the cheesecloth were washed with $400 \mathrm{~mL}$ of $0.85 \%$ (wt/ vol) $\mathrm{NaCl}$ solution and squeezed again; and filtrates (equivalent to $\mathrm{FP}+\mathrm{SP}$ ) were pooled together, stored on ice, and processed later that day for FAB isolation. The solids retained on the cheesecloth (equivalent to the LP phase) were transferred to a $500-\mathrm{mL}$ bottle; 350 $\mathrm{mL}$ of $0.85 \%$ (wt/vol) $\mathrm{NaCl}$ containing $0.1 \%$ (vol/vol) Tween- 80 and cooled to $5^{\circ} \mathrm{C}$ was added; and bottle contents were mixed thoroughly and stored on ice until processed for $\mathrm{PAB}$ isolation. Filtrates for $\mathrm{FAB}$ isolation were centrifuged $\left(1,000 \times g, 5^{\circ} \mathrm{C}, 5 \mathrm{~min}\right)$; pellets were saved and supernatants were carefully decanted and recentrifuged $\left(11,300 \times g, 5^{\circ} \mathrm{C}, 30 \mathrm{~min}\right)$; supernatants were decanted and discarded; and pellets were resuspended in $100 \mathrm{~mL}$ of McDougall's buffer and recentrifuged $\left(11,300 \times g, 5^{\circ} \mathrm{C}, 30 \mathrm{~min}\right)$. The resulting $\mathrm{FAB}$ pellets were stored at $-20^{\circ} \mathrm{C}$ until freeze-dried and ground with a mortar and pestle for later analysis. Pellets from the $1,000 \times g$ centrifugation step were mixed with the contents of the $500-\mathrm{mL}$ bottles saved for PAB isolation (equivalent to SP + LP), blended for 20 s using a blender (Waring Products Division, New Hartford, CT), transferred back to the bottles, and stored at $5^{\circ} \mathrm{C}$ for $24 \mathrm{~h}$. Blended contents were squeezed through 2 layers of cheesecloth and the filtrates were centrifuged $\left(1,000 \times g, 5^{\circ} \mathrm{C}, 5 \mathrm{~min}\right)$; supernatants were carefully decanted and recentrifuged $\left(11,300 \times g, 5^{\circ} \mathrm{C}\right.$, $30 \mathrm{~min}$ ). Supernatants were decanted and discarded, and pellets were resuspended in $100 \mathrm{~mL}$ of McDougall's buffer and recentrifuged $\left(11,300 \times g, 5^{\circ} \mathrm{C}, 30 \mathrm{~min}\right)$. The resulting $\mathrm{PAB}$ pellets were stored at $-20^{\circ} \mathrm{C}$ until freezedried and were ground with a mortar and pestle for later analysis. Composites were prepared by mixing equal amounts of DM from d 1, 2, and 3, to obtain 1 sample each of $\mathrm{FAB}$ and $\mathrm{PAB} / \mathrm{cow}$ per period. Each bacterial composite sample represented a 24 -h feeding cycle. The ${ }^{15} \mathrm{NB}$ samples were frozen, freeze-dried, then sequentially ground through a $1-\mathrm{mm}$ screen and through a 0.5-mm screen with a Udy Cyclone sample mill and stored for later analyses.

In addition, ruminal bacteria $(\mathbf{R B})$ were isolated from samples $(1,000 \mathrm{~mL})$ of whole ruminal contents obtained from the reticulum near the reticulo-omasal orifice at 6 separate postfeeding times $(0,2,4,6,8$, and $10 \mathrm{~h})$ during the last $3 \mathrm{~d}$ of each period. Ruminal samples were blended using a blender (Waring Products Division) at low speed for 1 min and strained through 6 layers of cheesecloth, and the filtrate was centrifuged at $500 \times g$ for $15 \mathrm{~min}$ at $4^{\circ} \mathrm{C}$. Supernatants were carefully decanted and recentrifuged $\left(18,000 \times g, 15 \mathrm{~min}, 4^{\circ} \mathrm{C}\right)$. Supernatants were decanted and discarded, and pellets were washed with $0.9 \% \mathrm{wt} / \mathrm{vol} \mathrm{NaCl}$ solution and recentrifuged $\left(18,000 \times g\right.$ for $15 \mathrm{~min}$ at $\left.4^{\circ} \mathrm{C}\right)$. The resulting 6 pellets from each cow were pooled and stored at $-20^{\circ} \mathrm{C}$ until freeze-dried and ground with a mortar and pestle for later analysis.

The individual purines adenine and guanine and their metabolites xanthine and hypoxanthine were determined in samples of PAB, FAB, RB, OTD, and duodenal digesta using the HPLC method of Balcells et al. (1992), as described by Reynal et al. (2003). The sum of the purines and their metabolites was defined as total purines (Reynal et al., 2005). Samples of ${ }^{15} \mathrm{NB}$, FAB, PAB, RB, FP, SP + LP, and duodenal digesta (100 $\mu \mathrm{g}$ of $\mathrm{N}$ ) were weighed into tin cups and $50 \mu \mathrm{L}$ of 72 $\mathrm{m} M \mathrm{~K}_{2} \mathrm{CO}_{3}$ solution were added to raise the $\mathrm{pH}$ to 12 . Capsules were placed in a $60^{\circ} \mathrm{C}$ oven for $24 \mathrm{~h}$ to volatil- 
ize ammonia. Samples were then analyzed for NAN and

${ }^{15} \mathrm{~N}$ atom\% enrichment (APE) of NAN by isotope ratio mass spectrometry (Stable Isotope Facility, Department of Agronomy and Range Science, University of California-Davis, Davis, CA).

\section{Calculations}

Flow of Digesta. Digesta flow to the omasum was calculated from the concentrations of $\mathrm{Co}, \mathrm{Yb}$, and INDF in omasal digesta phases using the triple-marker method of France and Siddons (1986). Digesta flow into the duodenum was calculated using $\mathrm{Cr}, \mathrm{Yb}$, or $\mathrm{Co}$ as an external marker (Van Soest, 1994).

Flow of $\boldsymbol{N}$ Fractions. The ${ }^{15} \mathrm{~N}$ APE (above natural background) was calculated for digesta and microbial samples from each cow in each period as follows:

$$
{ }^{15} \mathrm{~N} \text { APE }={ }^{15} \mathrm{~N} \text { atom } \%-{ }^{15} \mathrm{NB} .
$$

The ${ }^{15} \mathrm{~N}$ APE and total purines and NAN concentration in total omasal bacteria (TB) were calculated from the ${ }^{15} \mathrm{~N}$ APE, NAN, and purine contents of FAB and PAB and their proportions in omasal true digesta samples based on the triple-marker method. Microbial NAN flows into the omasal canal and duodenum were calculated using $\mathrm{FAB}, \mathrm{PAB}, \mathrm{TB}$, and $\mathrm{RB}$ as the bacterial reference and ${ }^{15} \mathrm{~N}$ or total purines as microbial markers as follows:

$$
\begin{aligned}
& \text { microbial NAN flow }(\mathrm{g} / \mathrm{d})=\text { digesta flow }(\mathrm{g} / \mathrm{d}) \\
& \times \text { NAN in digesta }(\mathrm{g} / \mathrm{g}) \times{ }^{15} \mathrm{~N} \text { atom\% excess }
\end{aligned}
$$

in digesta $/{ }^{15} \mathrm{~N}$ atom\% excess in bacterial reference;

$$
\begin{aligned}
& \text { microbial NAN flow }(\mathrm{g} / \mathrm{d})=\text { digesta flow }(\mathrm{g} / \mathrm{d}) \\
& \times \text { purines in digesta }(\mu \mathrm{mol} / \mathrm{g}) \times \mathrm{g} \text { of NAN } / \mu \mathrm{mol} \\
& \text { of purines in bacterial reference. }
\end{aligned}
$$

Similarly, microbial efficiencies [g of microbial N/kg of $\mathrm{OM}$ truly digested in the rumen (i.e., measured at the omasal canal) or whole stomach (i.e., measured at the duodenum)], nonammonia nonmicrobial $\mathrm{N}$ (NANMN) flows at the omasal canal or duodenum, and true $\mathrm{N}$ digestibilities in the rumen or whole stomach were calculated using microbial NAN flows based on $\mathrm{FAB}, \mathrm{PAB}, \mathrm{TB}$, or $\mathrm{RB}$ as references and ${ }^{15} \mathrm{~N}$ or total purines as microbial markers. True $\mathrm{N}$ digestibilities in the rumen and whole stomach were calculated as follows: true ruminal $\mathrm{N}$ digestibility, $\%=$

[N intake, g/d - (omasal N flow, g/d

- omasal microbial $\mathrm{N}$ flow, g/d)] $\times 100 / \mathrm{N}$ intake, g/d;

true whole stomach $\mathrm{N}$ digestibility, $\%=$

[N intake, g/d - (duodenal $\mathrm{N}$ flow, g/d

- duodenal microbial $\mathrm{N}$ flow, $\mathrm{g} / \mathrm{d}$ )]

$$
\times 100 / \mathrm{N} \text { intake, g/d. }
$$

\section{Statistical Analyses}

Data were analyzed using the GLM procedure of SAS (SAS Institute, 1999). The effects of using different bacterial references for calculating microbial and nonmicrobial NAN flows at the omasal canal and duodenum were assessed using the following split-plot model:

$$
\begin{gathered}
\mathrm{Y}_{\mathrm{ijkl}}=\mu+\mathrm{C}_{\mathrm{i}}+\mathrm{P}_{\mathrm{j}}+\mathrm{T}_{\mathrm{k}}+\omega_{\mathrm{ijk}}+\mathrm{B}_{\mathrm{l}} \\
+\mathrm{CB}_{\mathrm{il}}+\mathrm{PB}_{\mathrm{jl}}+\mathrm{TB}_{\mathrm{kl}}+\varepsilon_{\mathrm{ijk}},
\end{gathered}
$$

where C, P, T, B are cow (random), period (fixed), treatment, and bacterial reference effects, respectively, and $\omega$ and $\varepsilon$ are the whole-plot and split-plot error, respectively. The same model was used to assess the effects of microbial marker $\left({ }^{15} \mathrm{~N}\right.$ vs. total purines) on microbial and nonmicrobial NAN flows at the omasal canal and duodenum and the effects of digesta sampling site and duodenal digesta flow marker (omasal digesta vs. duodenal digesta calculated using $\mathrm{Co}, \mathrm{Yb}$, or $\mathrm{Cr}$ as a marker) on the flows and digestibilities of nutrients. Interactions between treatment, digesta sampling site, and microbial marker were assessed using the following split-plot model:

$$
\begin{gathered}
\mathrm{Y}_{\mathrm{ijklm}}=\mu+\mathrm{C}_{\mathrm{i}}+\mathrm{P}_{\mathrm{j}}+\mathrm{T}_{\mathrm{k}}+\delta_{\mathrm{ijk}}+\mathrm{M}_{1}+\mathrm{CM}_{\mathrm{il}} \\
+\mathrm{PM}_{\mathrm{jl}}+\mathrm{TM}_{\mathrm{kl}}+\gamma_{\mathrm{ijkl}}+\mathrm{S}_{\mathrm{m}}+\mathrm{SC}_{\mathrm{im}}+\mathrm{SP}_{\mathrm{jm}} \\
+\mathrm{ST}_{\mathrm{km}}+\omega_{\mathrm{ijkm}}+\mathrm{MS}_{\mathrm{lm}}+\mathrm{CMS}_{\mathrm{ilm}}+\mathrm{PMS}_{\mathrm{jlm}} \\
+\mathrm{TMS}_{\mathrm{klm}}+\varepsilon_{\mathrm{ijklm}}
\end{gathered}
$$

where C, P, T, M, and S are cow (random), period (fixed), treatment, microbial marker, and sampling site effects, respectively, and $\delta, \gamma, \omega$, and $\varepsilon$ are the errors. Values reported are least squares means that were separated into significant main effects using Fisher's protected least significant difference. Differences among treatments were considered to be significant when $P \leq 0.05$. 
OMASAL VERSUS DUODENAL SAMPLING

Table 2. Chemical composition of silages and concentrate mixes ${ }^{1}(\%$ of DM)

\begin{tabular}{lcccccr}
\hline Item & $\begin{array}{c}\text { Alfalfa } \\
\text { silage }\end{array}$ & $\begin{array}{c}\text { Corn } \\
\text { silage }\end{array}$ & $\begin{array}{c}\text { Urea } \\
\text { concentrate }\end{array}$ & $\begin{array}{c}\text { SSBM } \\
\text { concentrate }\end{array}$ & $\begin{array}{c}\text { XSBM } \\
\text { concentrate }\end{array}$ & $\begin{array}{c}\text { CGM } \\
\text { concentrate }\end{array}$ \\
\hline $\mathrm{OM}$ & 88.0 & 95.0 & 90.3 & 89.6 & 89.6 & 91.1 \\
$\mathrm{CP}$ & 22.5 & 8.8 & 29.3 & 16.8 & 17.1 & 26.0 \\
$\mathrm{NDF}$ & 39.0 & 33.5 & 9.0 & 9.0 & 12.4 & 6.6 \\
$\mathrm{ADF}$ & 30.0 & 18.7 & 2.1 & 2.9 & 3.4 & 1.7 \\
Starch & 0.46 & 31.6 & 45.2 & 42.4 & 40.8 & 33.7 \\
\hline
\end{tabular}

${ }^{1} \mathrm{SSBM}=$ solvent-extracted soybean meal; XSBM = xylose-treated soybean meal; CGM = corn gluten meal.

\section{RESULTS AND DISCUSSION}

\section{Diets and $\mathrm{pH}$ Measurements}

Although variation between percentages of dietary CP (i.e., both high and low) was larger than expected (Table 1), differences in the amount and source of protein allowed the comparison of the omasal and duodenal sampling techniques under a wide range of dietary conditions, which broadens the scope of our inferences. Diets had similar NDF, ADF, and starch contents, averaging $29.6,18.2$, and $27.4 \%$ of $\mathrm{DM}$, respectively. The chemical composition of the individual feeds is presented in Table 2.

On average, the $\mathrm{pH}$ of ruminal fluid, omasal digesta, and duodenal digesta were $6.14,6.57$, and 2.63 , respectively (Figure 1 ). These $\mathrm{pH}$ values were within normal physiological ranges (Church, 1971), suggesting that there was no apparent contamination of omasal samples with abomasal secretions or of duodenal samples with pancreatic secretions.

\section{Two- and Three-Way Interactions}

A significant $(P<0.05)$ interaction was detected between microbial marker (i.e., total purines and ${ }^{15} \mathrm{~N}$ ) and digesta sampling site for microbial NAN and NANMN flows, and true $\mathrm{N}$ digestibility in the rumen and whole stomach when $\mathrm{Cr}$ was used as the duodenal flow marker. Therefore, least squares means for the effects of bacterial reference on these variables were reported separately for total purines and ${ }^{15} \mathrm{~N}$ within digesta sampling site (Table 3). To test the effects of microbial marker within digesta sampling site, without the confounding effect of bacterial reference, TB was used as the bacterial reference for both omasal and duodenal calculations (Table 4). Because of the significant interaction between digesta sampling site and microbial marker, the effects of digesta sampling site on total NAN, microbial NAN, NANMN, RDP, and microbial efficiency were reported separately for ${ }^{15} \mathrm{~N}$ and total purines. The 3-way interaction among dietary treatment, digesta sampling site, and digesta flow marker was not significant $(P<0.25)$ for the postruminal flow and digestibility of $\mathrm{DM}, \mathrm{OM}$, starch, $\mathrm{NDF}$, and $\mathrm{ADF}$, or for the ruminal outflow of microbial NAN and NANMN and microbial efficiencies.

\section{Effect of Bacterial Reference}

Compared with TB, RB had higher NAN and total purine contents and a higher $\mathrm{N}$ :purine ratio (Table 3 ). However, ${ }^{15} \mathrm{~N}$ APE was not significantly different between TB and RB. Because populations of bacteria and protozoa present in omasal digesta appear to be representative of those inhabiting the rumen (Karnati et al., 2005), these findings suggest that differences in the procedures used to isolate TB and RB altered the species of bacteria harvested, their contribution to each bacterial reference, or both.

When using total purines as a microbial marker, microbial NAN flows at the omasal canal and duodenum were about 5 and $6 \%$ higher for $\mathrm{RB}$ than $\mathrm{TB}$, respectively (Table 3). Similarly, microbial NAN flows at both sites measured using ${ }^{15} \mathrm{~N}$ as a marker were $9 \%$ higher when $\mathrm{RB}$ rather than TB was used as a reference. When measured at the omasal canal using $\mathrm{RB}$ as a reference and ${ }^{15} \mathrm{~N}$ as a marker, flows of NANMN were lower and ruminal digestibility of $\mathrm{N}$ was higher than those based on TB. Although the ruminal outflow of $\mathrm{N}$ fractions and $\mathrm{N}$ digestibility followed similar trends across sampling sites, differences between bacterial references were significant only when these variables were measured at the omasal canal (Table 3). Based on these results and the apparently higher standard errors of measurement at the duodenum, it seems reasonable to suggest that omasal sampling was more precise than duodenal sampling to measure the impact of the bacterial reference on the ruminal outflow of $\mathrm{N}$ fractions. However, as will be discussed later, it is also possible that omasal sampling might be artificially sensitive, allowing it to reveal differences between bacterial references that otherwise would have required a larger sample size to reach significance.

In agreement with several reports from the literature (Craig et al., 1987; Carro and Miller, 2002; Reynal et al., 2005), N:purine ratios in $\mathrm{PAB}$ were $21 \%$ higher than 


\section{$\rightarrow-$ Rumen fluid \\ - O- Omasal digesta \\ $\rightarrow-$ Duodenal digesta}

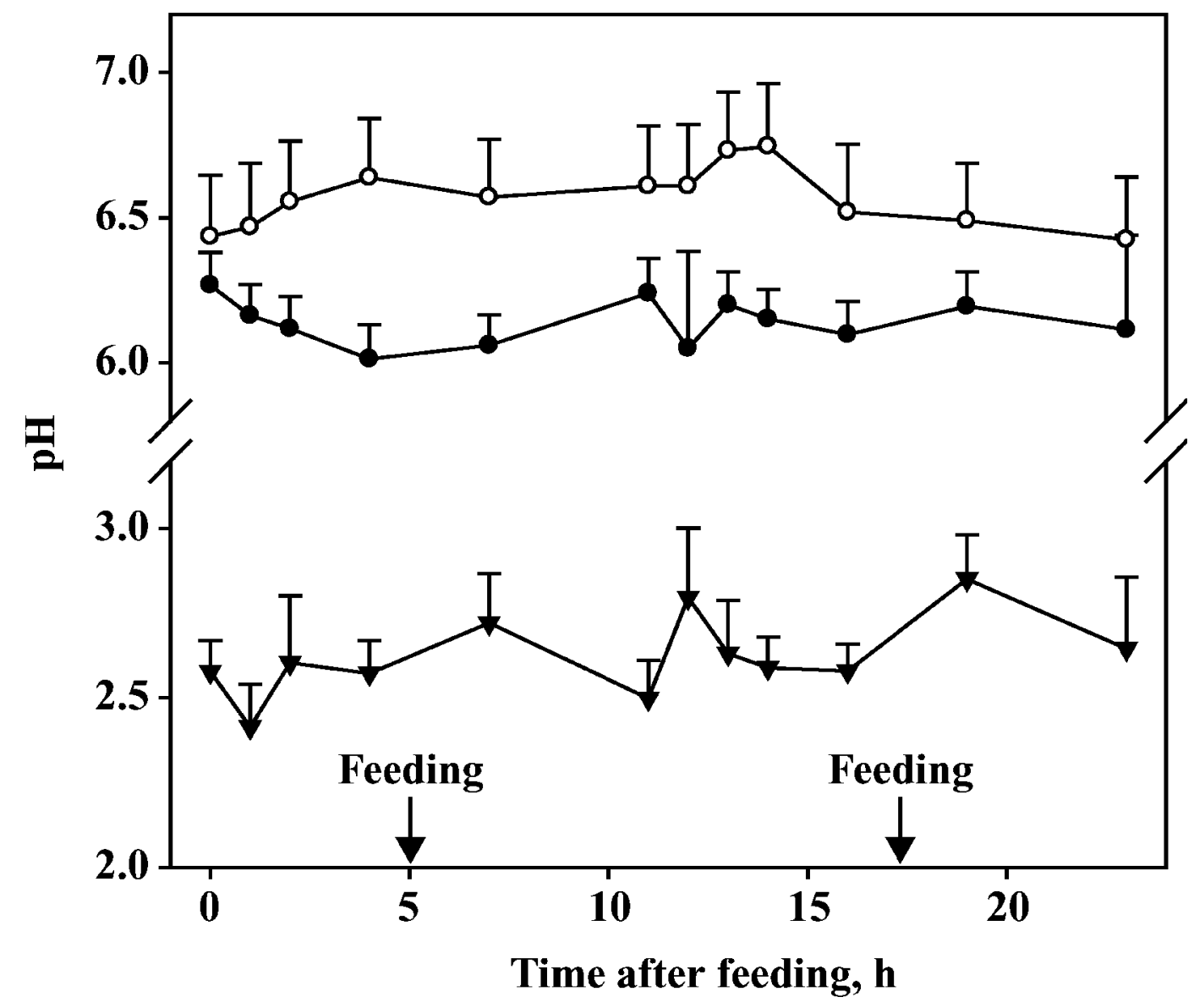

Figure 1. Diurnal $\mathrm{pH}$ of digesta samples obtained from the rumen, omasal canal, and duodenum of cows (bars represent SE).

those in FAB (Table 3). This resulted in microbial NAN flows at both the omasal canal and duodenum that were $22 \%$ higher when $\mathrm{PAB}$, rather than $\mathrm{FAB}$, was used as a reference. Similarly, Carro and Miller (2002) reported that the production of microbial protein in semicontinuous fermenters based on the N:purine ratio in FAB or $\mathrm{PAB}$ was either underestimated or overestimated by $16 \%$, respectively, compared with estimations based on the N:purine ratio of a mixed bacterial reference. Differences between $\mathrm{FAB}$ and $\mathrm{PAB}$ in the $\mathrm{N}$ :purine ratio have been attributed to the existence of 1) diverse bacterial species (Dehority and Orpin, 1988), 2) specific growth rates among species, 3) microenvironmental conditions (Bates et al., 1985; Legay Carmier and Bauchart, 1989) in the fluid and particulate phases of digesta, or 4) a combination of these factors.
The $9 \%$ lower ${ }^{15} \mathrm{~N}$ enrichment of PAB compared with FAB resulted in estimates of microbial NAN flow that were $9 \%$ higher than those estimated using FAB enrichment (Table 3). In the literature, ${ }^{15} \mathrm{~N}$ enrichments of FAB are reported to be from 6 (Rodriguez et al., 2000) to $15 \%$ (Ahvenjärvi et al., 2002) higher than those of $\mathrm{PAB}$. This might be the result of 1 ) a greater use of ammonia $\mathrm{N}$ as a $\mathrm{N}$ source by FAB than PAB (Faichney et al., 1997; Carro and Miller, 1999), or 2) differences between the growth rate of $\mathrm{FAB}$ and $\mathrm{PAB}$ and the rate at which ammonia, AA, and peptides were released in the rumen for microbial utilization, or both.

Although bacteria associated with particulate matter can account for 70 to $75 \%$ of the total bacteria in the rumen (Legay Carmier and Bauchart, 1989; Hristov and Broderick, 1996), higher passage rates of liquids 
Table 3. Composition of bacteria isolated from different digesta pools, and $\mathrm{N}$ flows at the omasal canal and duodenum measured using different bacterial references

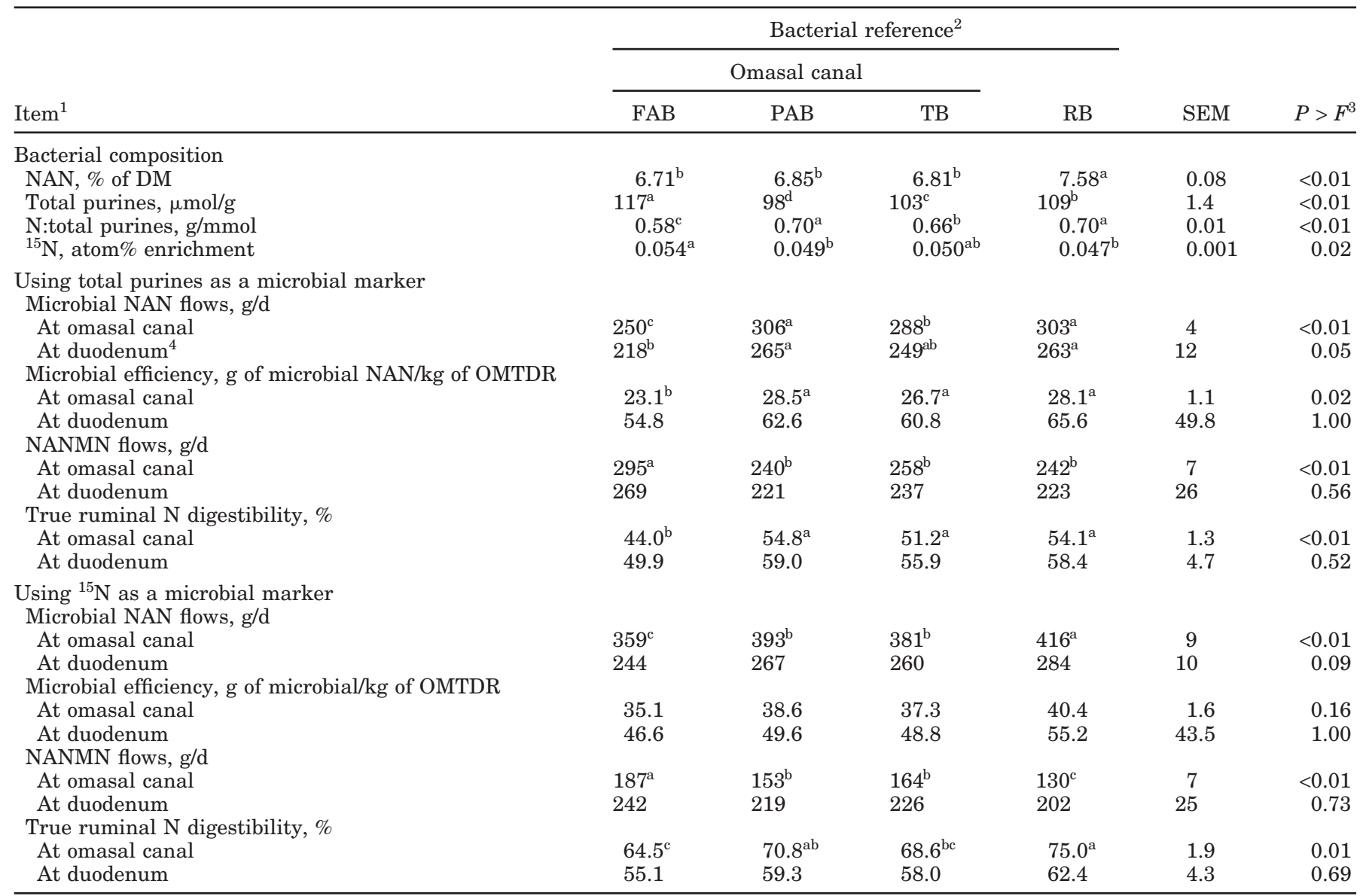

${ }^{\mathrm{a}-\mathrm{c}}$ Mean values within the same row without a common superscript differ $(P<0.05)$.

${ }^{1}$ OMTDR $=$ OM truly digested in the rumen; NANMN = nonammonia nonmicrobial $\mathrm{N}$.

${ }^{2}$ Bacteria isolated from the liquid (fluid-associated bacteria, FAB) and particle (particle-associated bacteria, PAB) omasal digesta phases and from the reticulorumen (ruminal bacteria, $\mathrm{RB}$ ), and total omasal bacteria reconstituted based on markers (total omasal bacteria, TB).

${ }^{3}$ Probability of a significant effect of the bacterial reference.

${ }^{4}$ Based on DM flow measurements using $\mathrm{Cr}$ as a digesta flow marker.

than particles may result in similar proportions of $\mathrm{PAB}$ and $\mathrm{FAB}$ in total bacterial $\mathrm{N}$ flows from the rumen (Hristov and Broderick, 1996). In the present study, however, $72 \%$ of the bacterial flow at the omasal canal was associated with the particle phase based on triplemarker computations (data not shown). Similarly, PAB accounted for $72 \%$ of the bacterial $\mathrm{N}$ flow at the omasal canal in the study of Ahvenjärvi et al. (2002). Therefore, when TB are used as the bacterial reference and their enrichment is not directly assessed, it appears that the marker concentrations in $\mathrm{FAB}$ and $\mathrm{PAB}$ and the relative contributions of these microbial fractions must be used to obtain representative measurements of microbial $\mathrm{N}$ flow.

\section{Effect of Microbial Marker}

Comparisons between ${ }^{15} \mathrm{~N}$ and total purines as microbial markers reported in the literature are inconclusive. Microbial $\mathrm{N}$ flows measured in vivo or in continuous cultures using ${ }^{15} \mathrm{~N}$ were lower than (Carro and Miller, 2002), higher than (Perez et al., 1996), or similar to (Hristov et al., 2005; Reynal et al., 2005) those estimated using total purines. In the present study, the impact of microbial marker on the ruminal outflow of $\mathrm{N}$ fractions and $\mathrm{N}$ digestibility depended on the sampling site. When digesta were sampled from the omasal canal, the use of ${ }^{15} \mathrm{~N}$ as a microbial marker resulted in higher ruminal outflow of microbial NAN, true $\mathrm{N}$ digestibility, and microbial efficiency but lower ruminal escape of 
Table 4. Comparison between ${ }^{15} \mathrm{~N}$ and total purines as microbial markers used with omasal canal and duodenal sampling techniques ${ }^{1}$

\begin{tabular}{lcrrr}
\hline & & Total & & \\
Item & ${ }^{15} \mathrm{~N}$ & purines & SEM & $P>F^{2}$ \\
\hline Microbial NAN flow, g/d & & & & \\
$\quad$ At omasal canal & 381 & 288 & 6 & $<0.01$ \\
$\quad$ At duodenum & 284 & 263 & 13 & 0.30 \\
$\quad$ NANMN flow, g/d & & & & \\
$\quad$ At omasal canal & 164 & 258 & 5 & $<0.01$ \\
$\quad$ At duodenum & 202 & 223 & 28 & 0.61 \\
$\quad$ True ruminal N digestibility, $\%$ & & & & \\
$\quad$ At the omasal canal & 68.6 & 51.2 & 2.4 & $<0.01$ \\
$\quad$ At duodenum & 62.4 & 58.3 & 4.8 & 0.56 \\
$\quad$ Microbial efficiency, g of microbial NAN/kg OMTDR & & & & \\
$\quad$ At the omasal canal & 37.3 & 26.7 & 1.2 & $<0.01$ \\
At duodenum & 55.2 & 65.6 & 48.9 & 0.88 \\
\hline
\end{tabular}

${ }^{1}$ Based on calculations using total omasal bacteria (TB) as a microbial reference and $\mathrm{Cr}$ as a marker to estimate digesta flow to the duodenum. NANMN = nonammonia nonmicrobial N; OMTDR = OM truly digested in the rumen.

${ }^{2}$ Probability of a significant effect of microbial marker.

NANMN than did total purines (Table 4). In contrast, none of these variables was significantly different between microbial markers when digesta samples were obtained from the duodenum (Table 4).

The proportion of xanthine, a metabolite of the degradation of adenine and guanine, in total purines (i.e., sum of adenine, guanine, xanthine, and hypoxanthine) was $6.2 \%$ for $\mathrm{FAB}, 11.0 \%$ for PAB, $24.9 \%$ for FP, and $13.5 \%$ for SP + LP. In contrast, xanthine concentrations in $\mathrm{RB}$ and duodenal digesta samples were 4.4 and $2.6 \%$ of total purines, respectively. This suggests that purines in omasal digesta phases were degraded to a greater extent than were purines in their corresponding bacterial references, leading to an underestimation of the omasal flow of microbial NAN relative to ${ }^{15} \mathrm{~N}$. The higher concentration of xanthine in omasal digesta and bacterial references might have resulted from the longer time required for isolation and processing of these samples compared with isolation of $\mathrm{RB}$ and immediate freezing of duodenal digesta after collection.

Interestingly, the difference between microbial markers for the flow of microbial NAN at the omasal canal (381 vs. $288 \mathrm{~g} / \mathrm{d})$ was as large as the difference between sampling sites for the same variable when ${ }^{15} \mathrm{~N}$, but not total purines, was used as a marker (381 vs. $284 \mathrm{~g} / \mathrm{d}$ ). As proposed earlier, a more extensive degradation of purine bases in omasal samples than in duodenal samples might have prevented detecting differences between sampling sites when total purines were used as microbial markers. This does not explain, however, why the use of ${ }^{15} \mathrm{~N}$ resulted in about $100 \mathrm{~g} / \mathrm{d}$ more microbial NAN passing to the omasum than the duodenum. As proposed later, it is likely that problems associated with the estimation of digesta flows at each sampling site accounted for this difference.

\section{Duodenal Sampling}

As shown in Table 5, duodenal DM flows calculated using $\mathrm{Co}$ and $\mathrm{Yb}$ as digesta markers were significantly correlated $(\mathrm{R}=0.99 ; P<0.01)$, with a slope of $0.98(P$ $<0.01)$ and an intercept of $2.39(P<0.08)$. However, flows based on $\mathrm{Cr}$ were poorly correlated with those based on Co (slope $=0.69)$ or $\mathrm{Yb}$ (slope $=0.71$ ). Duodenal flows of DM, OM, NDF, ADF, and microbial NAN were significantly lower when calculated using $\mathrm{Cr}$, higher when based on $\mathrm{Yb}$, and intermediate when Co was used as a marker (Tables 6 and 7). Duodenal flows of DM, $\mathrm{OM}$, and starch computed using $\mathrm{Co}$ or $\mathrm{Yb}$ were always distinctly higher than their intakes, resulting in negative, and therefore biologically improbable, whole-stomach digestibilities.

It should be noted that one cow had extremely high starch concentrations in duodenal digesta $(38,44$, and $49 \%$ of DM in periods 1,3 , and 4 , respectively). Averaged across periods, this cow had intakes of DM and starch of 21.5 and $5.5 \mathrm{~kg} / \mathrm{d}$, respectively; estimated flows of DM and starch of 25 and $9 \mathrm{~kg} / \mathrm{d}$, respectively; and apparent ruminal digestibilities of DM and starch of -16 and $-65 \%$, respectively. A potential explanation for the unreliable findings for this animal may include malfunction of its duodenal cannula or, alternatively, higher sensitivity than the other cows to mechanical perturbations at the duodenum during sampling. Titgemeyer (1997) suggested that, when feeding mixed or high-grain diets, particles of grain could be selectively collected during digesta sampling. This may occur because sudden alterations of the pressure gradient between the abomasum and duodenum caused by either incomplete (i.e., simple-T cannula) or complete (i.e., enclosed-T cannula) diversion of digesta during sampling 
Table 5. Relationships between omasal canal (based on a triple-marker method) and duodenal (based on $\mathrm{Cr}$ ) measurements of nutrient flows, and between $\mathrm{Co}, \mathrm{Yb}$, and $\mathrm{Cr}$ as duodenal flow markers

\begin{tabular}{llcr}
\hline Variable & Regression equation ${ }^{1}$ & $P$-value & $\mathrm{R}$ \\
\hline M regressed on D & & & \\
DM, kg/d & $M=0.09 D+10.4$ & 0.20 & 0.39 \\
OM, kg/d & $M=0.06 D+8.74$ & 0.33 & 0.31 \\
NAN, g/d & $M=1.01 D+99$ & \\
Microbial NAN, g/d & $M=0.47^{* *} D+162^{* *}$ & \\
Total purines & $M=0.38 D+274$ & 0.73 \\
${ }^{15}$ N & $M=0.05 D+2.57$ & $<0.01$ & 0.49 \\
NDF, kg/d & $M=-0.002 D+0.77^{* *}$ & 0.11 & 0.08 \\
Starch, kg/d & & 0.86 & 0.06 \\
Duodenal DM flows, kg/d & $Y b=0.98^{* *} C o+2.39$ & 0.99 \\
Yb vs. Co & $C r=0.69^{* *} C o+0.25$ & \\
Cr vs. Co & $C r=0.71^{* *} Y b-1.68$ & $<0.01$ & 0.88 \\
Cr vs. Yb & & $<0.01$ & 0.91 \\
\hline
\end{tabular}

${ }^{1} M=$ omasal canal flow, $D=$ duodenal flow.

**Significant at $P<0.01$.

could increase the intensity or frequency of abomasal contractions, or both (Ruckebusch, 1988; Robinson and Kennelly, 1990), leading to expulsion of dense particles (kernels) that otherwise would tend to settle in the fundic area of the organ (Grovum and Williams, 1973; Faichney, 1980). This in turn would result in an overestimation of starch flow, and therefore an underestimation of ruminal starch digestibility. In addition, enrich- ment of digesta samples with particles may dilute the concentration of certain markers, mainly those associated with the fluid phase, resulting in overestimation of digesta flows. In fact, when questionable data from the particular animal were included in calculations, the starch content in duodenal digesta (as \% of DM) and estimated $\mathrm{DM}$ flow at the duodenum based on $\mathrm{Co}, \mathrm{Yb}$, and $\mathrm{Cr}$ were highly correlated $(\mathrm{R}=0.76,0.83$, and 0.84 ,

Table 6. Intake, digestibility, and flow into the omasal canal (based on a triple-marker method) and into the duodenum (based on single markers) of DM, OM, starch, and fiber

\begin{tabular}{|c|c|c|c|c|c|c|c|}
\hline \multirow[b]{3}{*}{ Item } & \multirow[b]{3}{*}{ Intake } & \multicolumn{4}{|c|}{ Digesta sampling site } & \multirow[b]{3}{*}{$\mathrm{SE}$} & \multirow[b]{3}{*}{$P>F$} \\
\hline & & \multirow{2}{*}{$\begin{array}{c}\text { Omasal } \\
\text { canal }^{1}\end{array}$} & \multicolumn{3}{|c|}{ Duodenum } & & \\
\hline & & & Co & $\mathrm{Yb}$ & $\mathrm{Cr}$ & & \\
\hline \multicolumn{8}{|l|}{$\mathrm{DM}$} \\
\hline Intake, $\mathrm{kg} / \mathrm{d}$ & 19.7 & & & & & & \\
\hline Flow, kg/d & & $12.7^{\mathrm{d}}$ & $23.8^{\mathrm{b}}$ & $25.7^{\mathrm{a}}$ & $16.6^{\mathrm{c}}$ & 0.5 & $<0.01$ \\
\hline $\mathrm{ADR}^{2} \%$ & & $35.0^{\mathrm{a}}$ & $-20.5^{\mathrm{c}}$ & $-30.9^{\mathrm{d}}$ & $16.2^{\mathrm{b}}$ & 2.9 & $<0.01$ \\
\hline \multicolumn{8}{|l|}{$\mathrm{OM}$} \\
\hline Intake, kg/d & 18.1 & & & & & & \\
\hline Flow, kg/d & & $10.2^{\mathrm{d}}$ & $21.0^{\mathrm{b}}$ & $22.7^{\mathrm{a}}$ & $14.6^{\mathrm{c}}$ & 0.5 & $<0.01$ \\
\hline $\mathrm{ADR}, \%$ & & $43.2^{\mathrm{a}}$ & $-16.1^{\mathrm{c}}$ & $-26.0^{\mathrm{d}}$ & $19.3^{\mathrm{b}}$ & 3.0 & $<0.01$ \\
\hline \multicolumn{8}{|l|}{ Starch } \\
\hline Intake, kg/d & 5.36 & & & & & & \\
\hline Flow, kg/d & & $0.75^{\mathrm{c}}$ & $7.12^{\mathrm{ab}}$ & $7.67^{\mathrm{a}}$ & $4.98^{\mathrm{b}}$ & 0.81 & $<0.01$ \\
\hline $\mathrm{ADR}, \%$ & & $86.0^{\mathrm{a}}$ & $-30.4^{\mathrm{bc}}$ & $-40.4^{\mathrm{c}}$ & $9.0^{\mathrm{b}}$ & 16.0 & $<0.01$ \\
\hline \multicolumn{8}{|l|}{$\mathrm{NDF}$} \\
\hline Intake, kg/d & 5.82 & & & & & & \\
\hline Flow, kg/d & & $2.86^{\mathrm{d}}$ & $4.96^{\mathrm{b}}$ & $5.38^{\mathrm{a}}$ & $3.42^{\mathrm{c}}$ & 0.16 & $<0.01$ \\
\hline $\mathrm{ADR}, \%$ & & $49.7^{\mathrm{a}}$ & $12.9^{\mathrm{b}}$ & $4.8^{\mathrm{b}}$ & $39.7^{\mathrm{a}}$ & 4.4 & $<0.01$ \\
\hline \multicolumn{8}{|l|}{$\mathrm{ADF}$} \\
\hline Intake, kg/d & 3.57 & & & & & & \\
\hline Flow, kg/d & & $1.46^{\mathrm{c}}$ & $2.63^{\mathrm{a}}$ & $2.86^{\mathrm{a}}$ & $1.83^{\mathrm{b}}$ & 0.11 & $<0.01$ \\
\hline $\mathrm{ADR}, \%$ & & $57.8^{\mathrm{a}}$ & $24.1^{\mathrm{b}}$ & $17.0^{\mathrm{b}}$ & $47.2^{\mathrm{a}}$ & 4.3 & $<0.01$ \\
\hline
\end{tabular}


Table 7. Intake of total NAN and flow of $\mathrm{N}$ fractions into the omasal canal and duodenum using different microbial and digesta flow markers ${ }^{1}$

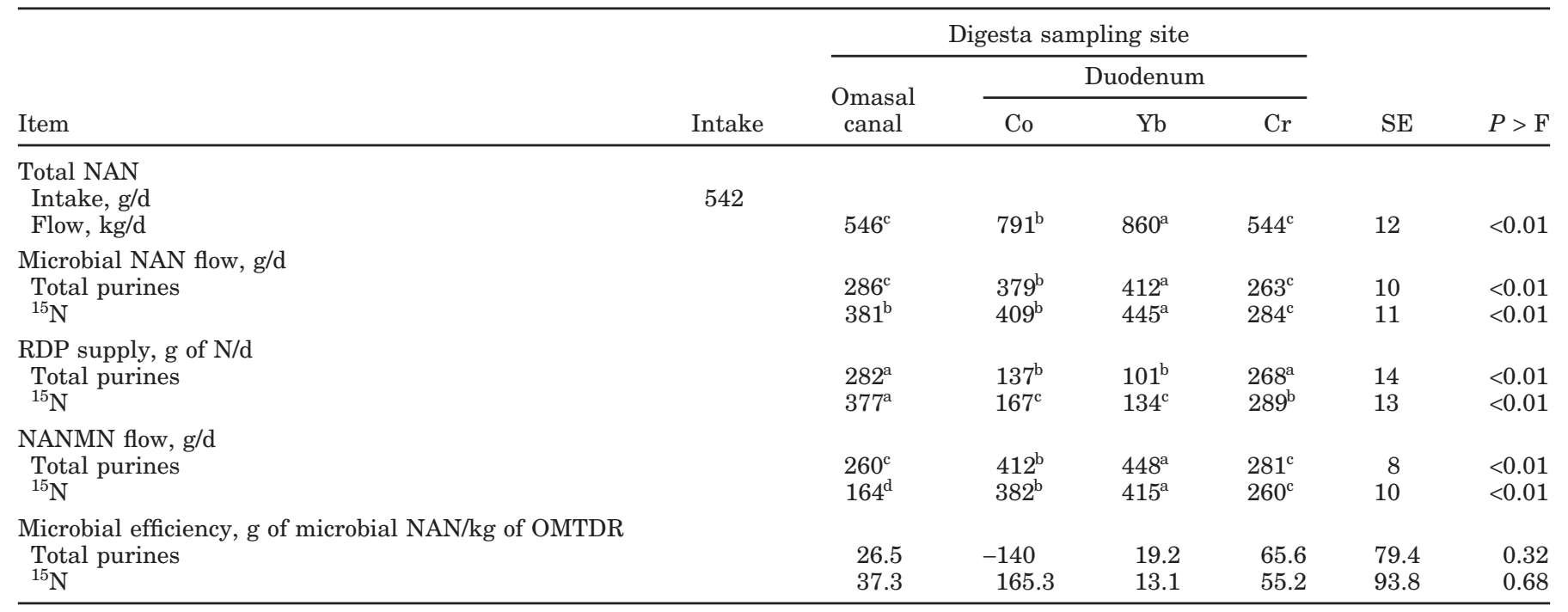

${ }^{\mathrm{a}-\mathrm{d}}$ Mean values within the same row without a common superscript $\operatorname{differ}(P<0.05)$.

${ }^{1}$ Total omasal bacteria (TB) isolated from the omasum were used as a reference for omasal and duodenal digesta flows. NANMN $=$ nonammonia nonmicrobial N; OMTDR = OM truly digested in the rumen.

respectively; Figure 2). Furthermore, mean duodenal $\mathrm{DM}$ flows for all cows estimated using $\mathrm{Yb}$ and Co were, on average, 59 and $46 \%$ higher than Cr-based flows. Cobalt is mainly associated with the fluid phase (Uden et al., 1980) and $\mathrm{Yb}$ is mainly associated with small particles (Siddons et al., 1985) that may escape the rumen at rates similar to the fluid phase (Reynal and Broderick, 2003). Therefore, it is possible that at least for the cow with large digesta flow values, enrichment of duodenal digesta samples with particles might have given similar dilutions of the $\mathrm{Co}$ and $\mathrm{Yb}$, resulting in the collection of samples that did not represent true digesta. On the other hand, because chromic oxide dosed directly into the rumen does not associate with any phase when flowing through the gut (Merchen, 1988), estimations of digesta flows based on $\mathrm{Cr}$ might have been less sensitive to incorrect contributions of digesta phases in duodenal samples because the concentration of $\mathrm{Cr}$ was probably affected less than that of $\mathrm{Co}$ and $\mathrm{Yb}$.

Another possible source of error is associated with determination of marker concentrations in duodenal digesta, which may result in biased estimations of duodenal flow. However, there was no evidence suggesting biased analytical results in our trial. Average regression coefficients of analytical standard curves used to calculate unknown marker concentrations were equal to 1.00 for all markers. Moreover, average recoveries of known amounts of $\mathrm{Co}$ and $\mathrm{Yb}$ added to digesta samples were, respectively, 99 and 106\%. Coefficients of variation between replicates averaged 1.6, 2.6, and $1.4 \%$ for
$\mathrm{Co}, \mathrm{Yb}$, and $\mathrm{Cr}$, respectively. To determine whether digesta samples are representative of true digesta, Titgemeyer (1997) proposed using markers for different phases and verifying that marker ratios between digesta samples and the amounts administered to the animal are similar. In the present study, Cr:Co and $\mathrm{Cr}: \mathrm{Yb}$ ratios were 5.2 and 3.7 in infusates, respectively. However, mean marker ratios in duodenal digesta from each of the 3 animals were 7.2, 7.9, and 7.8 for $\mathrm{Cr}$ :Co and 5.5, 6.4, and 6.0 for $\mathrm{Cr}: \mathrm{Yb}$, respectively, suggesting that samples were not representative.

One might speculate that total collection of digesta from animals fitted with reentrant cannulas might provide an alternative to solve this problem. However, reentrant cannulas can cause abnormal propulsion and flow of digesta, they can interfere with animal performance (Wenham and Wyburn, 1980), and data obtained may not accurately represent physiologically normal cattle (Robinson and Kennelly, 1990). Consequently, there is no way to determine with absolute certainty whether digesta samples collected at the duodenum of cattle fitted with closed-T cannulas are representative of true digesta flowing though the duodenum.

\section{Omasal Canal Sampling}

Digesta phases are prone to separation when samples are obtained by aspirating through a tube or from a simple-T cannula. To overcome this limitation, France and Siddons (1986) proposed the use of a triple-marker method to reconstitute mathematically the true digesta 


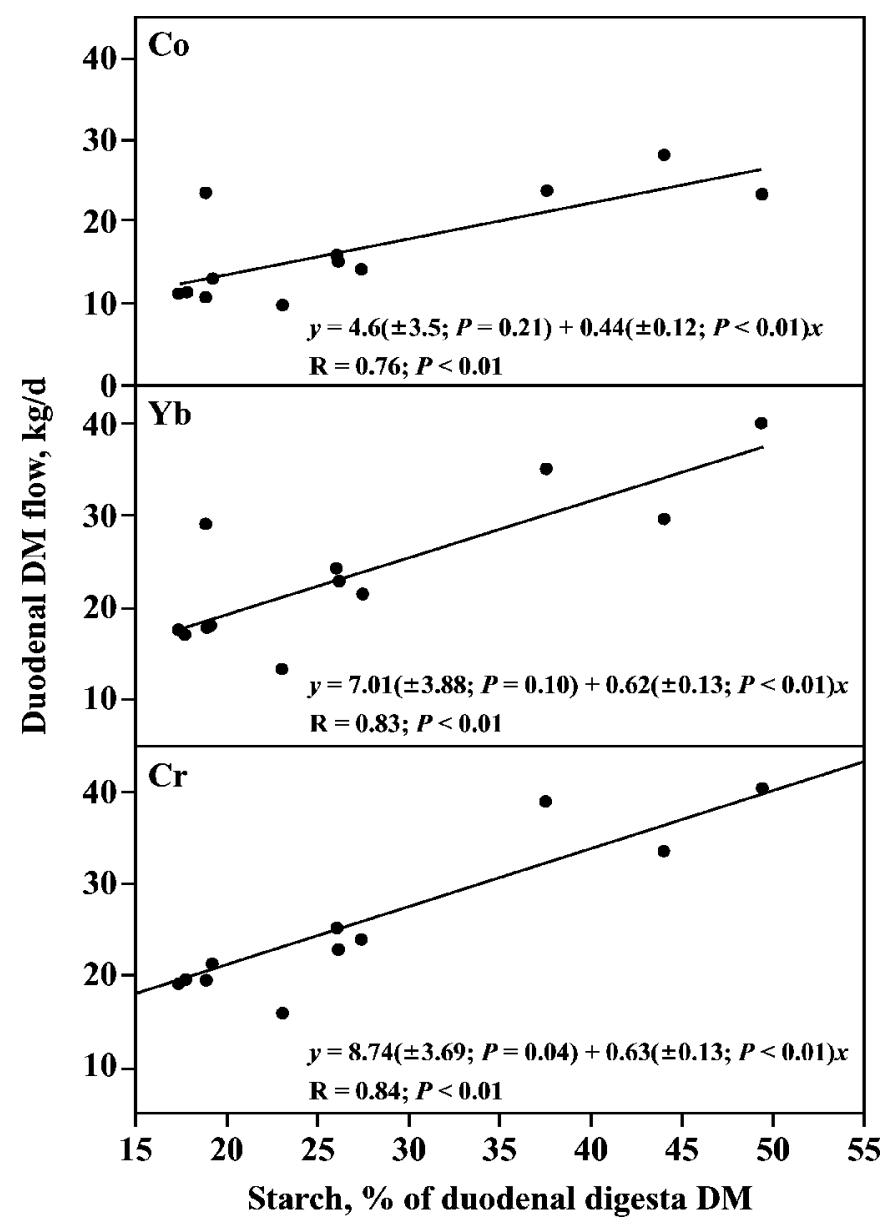

Figure 2. Relationship between the starch content in duodenal digesta and duodenal $\mathrm{DM}$ flow measured using $\mathrm{Co}, \mathrm{Yb}$, and $\mathrm{Cr}$ as markers.

by combining 3 independent phases (FP, SP, and LP) in the proportions flowing past the cannula. This approach assumes that digesta samples are truly representative of each phase but not of total digesta. Implicitly, this means that the size and the physical and chemical composition of digesta phases in samples that are not representative are considered to be the same as in true digesta (Faichney, 1993). However, when digesta are aspirated from the omasal canal, particles with different functional specific gravities may segregate as they travel through the sample tube. This could result in flows of particles of high specific gravity (e.g., corn kernels) being underestimated. Likewise, sieving of large particulate matter (e.g., long fiber particles) during aspiration through the sampling tube could also result in incorrect mixtures of digesta fractions in the samples. This would not only lead to an underestimation of the contribution of large particles to the flow of total digesta at the omasal canal, but also to the outflow of nutrients that exit the rumen in close association with the LP phase (e.g., starch trapped in whole or partly broken kernels). Consequently, mathematical estimates of the flows of the other 2 phases (i.e., FP and SP) at the omasum and nutrients associated with them would be biased as well (i.e., overestimated).

Ruminal starch digestibilities measured using the omasal sampling technique averaged 86\% across diets (Table 6). Data compiled by Reynolds et al. (1997) indicate that the proportion of starch intake that was apparently digested in the rumen of lactating dairy cows fitted with duodenal cannulas and fed 25 different diets containing corn grain either ground, rolled, or flaked ranged from 31 to $69 \%$ and averaged $48 \%$. It is therefore likely that in this trial, corn kernels were segregated during sampling, resulting in underestimation of starch flows and overestimation of starch digestibility in the rumen. In addition, ruminal digestibilities of NDF and ADF determined using omasal sampling were higher than total tract digestibilities calculated using $\mathrm{Cr}$ as a marker (data not shown), which is in agreement with results from Ahvenjärvi et al. (2001) and suggests that the ruminal outflow of these fiber fractions was probably underestimated. Furthermore, when digesta were sampled from the omasum, the postruminal flow of microbial NAN was about $100 \mathrm{~g} / \mathrm{d}$ larger for ${ }^{15} \mathrm{~N}$ than total purines (Table 4). Interestingly, such a difference is as large as the difference found between the mean of 215 published observations for the flow of microbial $\mathrm{N}$ to the duodenum ( $268 \mathrm{~g} / \mathrm{d}$; Ipharraguerre and Clark, 2005) and the mean of 42 reported estimates for the flow of microbial $\mathrm{N}$ at the omasal canal (370 g/d; I. R. Ipharraguerre and S. M. Reynal, unpublished data). Because rumen bacteria pass to the lower digestive tract mainly attached to SP and as solutes in the FP (see above discussion), the flow of microbial NAN at the omasal canal might have been overestimated. This hypothesis is supported by the finding that the omasal flow of microbial NAN was strongly correlated with the proportional contribution of SP and FP to the reconstituted omasal digesta, but not with that of the LP (Figure 3). Therefore, it might be possible that at least a part of these differences occurred because reconstituted omasal samples contained larger proportions of small particles and liquid than true digesta, resulting from the loss of large particles during sampling. Independent of the validity of this assertion, the magnitude of the difference between starch and microbial $\mathrm{N}$ flows to the omasum and duodenum found in this experiment and in the literature warns that the extrapolation and interpretation of published results as well as the outcomes of their application in model parameterization and predictions should be carefully evaluated to avoid flawed generalizations. 


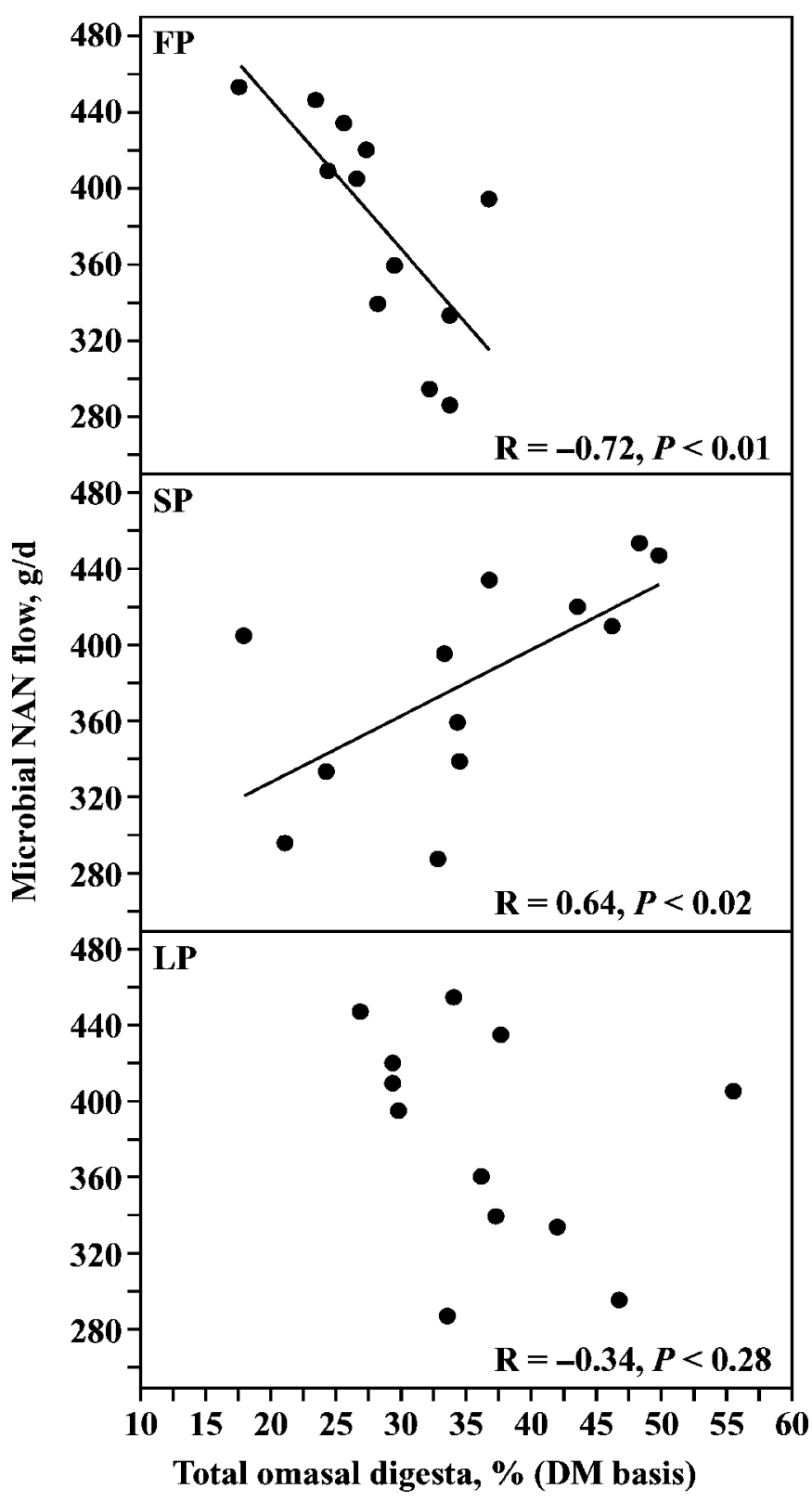

Figure 3. Relationship between the flow of microbial NAN at the omasal canal and the proportions of fluid phase (FP), small-particle phase (SP), and large-particle phase (LP) in total reconstituted omasal digesta.

\section{Omasal Canal vs. Duodenal Sampling}

In the present study, the agreement between flows measured at the omasal canal and duodenum depended on the digesta flow marker (Tables 5 and 6 ) and the cows used (Tables 8 and 9). Assuming that malfunction of the duodenal cannula occurred in one of the animals, data from the other 2 animals were summarized in Tables 8 and 9 using arithmetic means. Starch flows at the duodenum based on $\mathrm{Cr}$ were 3.7 times higher
Table 8. Arithmetic means of data from 2 cows for intake, digestibility, and flow into the omasal canal (based on a triple-marker method) and into the duodenum (based on single markers) of DM, OM, starch, and fiber

\begin{tabular}{|c|c|c|c|c|c|}
\hline \multirow[b]{3}{*}{ Item } & \multirow[b]{3}{*}{ Intake } & \multicolumn{4}{|c|}{ Digesta sampling site } \\
\hline & & \multirow{2}{*}{$\begin{array}{c}\text { Omasal } \\
\text { canal }^{1}\end{array}$} & \multicolumn{3}{|c|}{ Duodenum } \\
\hline & & & Co & $\mathrm{Yb}$ & $\mathrm{Cr}$ \\
\hline \multicolumn{6}{|l|}{$\mathrm{DM}$} \\
\hline Intake, $\mathrm{kg} / \mathrm{d}$ & 18.9 & & & & \\
\hline Flow, kg/d & & 12.4 & 19.0 & 20.8 & 12.6 \\
\hline $\mathrm{ADR},{ }^{2} \%$ & & 33.6 & -2.39 & -12.9 & 32.2 \\
\hline \multicolumn{6}{|l|}{$\mathrm{OM}$} \\
\hline Intake, $\mathrm{kg} / \mathrm{d}$ & 17.3 & & & & \\
\hline Flow, kg/d & & 10.0 & 16.5 & 18.1 & 10.9 \\
\hline $\mathrm{ADR}, \%$ & & 41.5 & 3.03 & -6.88 & 35.8 \\
\hline \multicolumn{6}{|l|}{ Starch } \\
\hline Intake, $\mathrm{kg} / \mathrm{d}$ & 5.27 & & & & \\
\hline Flow, kg/d & & 0.77 & 4.26 & 4.65 & 2.82 \\
\hline $\mathrm{ADR}, \%$ & & 85.6 & 18.4 & 10.6 & 46.0 \\
\hline \multicolumn{6}{|l|}{ NDF } \\
\hline Intake, $\mathrm{kg} / \mathrm{d}$ & 5.57 & & & & \\
\hline Flow, kg/d & & 2.79 & 4.59 & 5.05 & 3.04 \\
\hline $\mathrm{ADR}, \%$ & & 48.9 & 14.6 & 5.43 & 43.3 \\
\hline \multicolumn{6}{|l|}{$\mathrm{ADF}$} \\
\hline Intake, $\mathrm{kg} / \mathrm{d}$ & 3.44 & & & & \\
\hline Flow, kg/d & & 1.42 & 2.49 & 2.73 & 1.64 \\
\hline $\mathrm{ADR}, \%$ & & 57.6 & 24.5 & 16.5 & 49.9 \\
\hline
\end{tabular}

${ }^{1}$ Measured using $\mathrm{Co}, \mathrm{Yb}$, and indigestible NDF as digesta flow markers based on the triple-marker method of France and Siddons (1986).

${ }^{2}$ Apparently digested in the rumen.

than those measured at the omasal canal (2.82 vs. 0.77 $\mathrm{kg} / \mathrm{d}$; Table 8). Ruminal digestibility of starch was $86 \%$ higher when measured at the omasal canal, compared with the duodenum based on Cr. When estimated using ${ }^{15} \mathrm{~N}$, microbial NAN flows were $44 \%$ higher at the omasal canal compared with the duodenum using Cr. However, flows and digestibilities of DM, OM, NDF, and $\mathrm{ADF}$, as well as microbial NAN flow and efficiency based on total purines and RDP supply and NANMN flow based on either microbial marker, were similar between the omasal canal and duodenum based on $\mathrm{Cr}$ (data from 2 cows only; Tables 8 and 9). Nevertheless, duodenal flows and digestibilities based on $\mathrm{Co}$ and $\mathrm{Yb}$ were substantially different from those based on $\mathrm{Cr}$ and those measured at the omasal canal. Therefore, omasal canal and duodenal sampling yielded similar results for 2 of 3 cows and only when $\mathrm{Cr}$ was used as the duodenal digesta flow marker and total purines as the microbial marker.

In contrast, Ahvenjärvi et al. (2000) reported good agreement between omasal canal and duodenal sampling for the postruminal flow of some fiber and $\mathrm{N}$ fractions. A possible explanation for the discrepancies between our findings and those of Ahvenjärvi et al. (2000) may be related to different experimental conditions and 
Table 9. Arithmetic means of data from 2 cows for intake of total NAN and flow of $\mathrm{N}$ fractions into the omasal canal and duodenum using different microbial and digesta flow markers ${ }^{1}$

\begin{tabular}{|c|c|c|c|c|c|}
\hline \multirow[b]{3}{*}{ Item } & \multirow[b]{3}{*}{ Intake } & \multicolumn{4}{|c|}{ Digesta sampling site } \\
\hline & & \multirow{2}{*}{$\begin{array}{c}\text { Omasal } \\
\text { canal }\end{array}$} & \multicolumn{3}{|c|}{ Duodenum } \\
\hline & & & Co & $\mathrm{Yb}$ & $\mathrm{Cr}$ \\
\hline \multicolumn{6}{|l|}{ Total NAN } \\
\hline Intake, $\mathrm{g} / \mathrm{d}$ & 513 & & & & \\
\hline Flow, kg/d & & 543 & 734 & 806 & 485 \\
\hline \multicolumn{6}{|c|}{ Microbial NAN flow, g/d } \\
\hline Total purines & & 279 & 359 & 394 & 238 \\
\hline${ }^{15} \mathrm{~N}$ & & 371 & 388 & 427 & 258 \\
\hline \multicolumn{6}{|c|}{ RDP supply, g of N/d } \\
\hline Total purines & & 267 & 235 & 270 & 335 \\
\hline${ }^{15} \mathrm{~N}$ & & 359 & 264 & 303 & 354 \\
\hline \multicolumn{6}{|c|}{ NANMN flow, g/d } \\
\hline Total purines & & 264 & 296 & 261 & 197 \\
\hline${ }^{15} \mathrm{~N}$ & & 172 & 267 & 229 & 177 \\
\hline \multicolumn{6}{|c|}{ Microbial efficiency, g of microbial NAN/kg of OMTDR } \\
\hline Total purines & & 27.7 & -20.5 & 65.7 & 28.8 \\
\hline${ }^{15} \mathrm{~N}$ & & 38.9 & -19.9 & 65.1 & 30.3 \\
\hline
\end{tabular}

types of duodenal cannulas. The diets (grass silage, barley grain, and rapeseed meal) and feeding system (forage and concentrates offered separately) used by Ahvenjärvi et al. (2000) also differed substantially from our conditions and those prevalent in the United States (corn-based TMR) in terms of the physical and chemical characteristics. Differences in chemical composition and digestion kinetics between grass and legume forages and corn and barley grains may result in contrasting functional specific gravities and sizes of digesta particles leaving the rumen of dairy cows (Hooper and Welch, 1985; Ramanzin et al., 1994). If particles of highly fermentable grains, such as barley, do not tend to accumulate in the abomasal fundic area as much as less fermentable grains (e.g., corn), then mild abomasal stimulation during sampling from the duodenum when highly fermentable grains are fed may be more likely to result in samples that are representative of true digesta than when less fermentable grains are fed. Particles of some grains, such as barley, may also be less prone to segregation during aspiration through the omasal sampling tube, resulting in similar measured nutrient flows between sampling sites. In addition, cows used in the experiment of Ahvenjärvi et al. (2000) were restricted in DMI and consumed on average $5 \mathrm{~kg} /$ $d$ less DM than cows in our study. This might have caused a more extensive ruminal degradation of carbohydrates because of longer retention time in the rumen, such that digesta flowing at the omasal canal contained a smaller proportion of kernel pieces and large particles, reducing the likelihood of particle segregation during sampling. On the other hand, the use of simple T- type cannulas without total diversion of digesta in the study by Ahvenjärvi et al. (2000) might have resulted in less stimulation of abomasal emptying because of lower pressure changes, avoiding the propulsion of kernel pieces that were retained in the fundic portion of the abomasum. In light of these observations and the fact that the study by Ahvenjärvi et al. (2000) and this trial were the only experiments designed to compare omasal canal and duodenal sampling, more attention is needed to address how well nutrient flows at the omasum represent nutrient flows to the duodenum, particularly for nutrients that exit the rumen in close association with the SP (e.g., microbial protein, fatty acids).

\section{CONCLUSIONS}

Data reported here demonstrate that several methodological factors can contribute significant variation to the measurement of nutrients passing from the rumen to the lower digestive tract of dairy cows. Considerable variation was found for the composition of microbial references and its impact on the intestinal supply of microbial NAN, which reinforces the well-established need for quantifying the contribution of major microbial groups or targeted populations to the intestinal supply of AA. Our results also support the contention that using ${ }^{15} \mathrm{~N}$ rather than purines as a microbial marker may reduce the variation in estimating the ruminal outflow of NAN of microbial and dietary origin and would allow for the measurement of additional $\mathrm{N}$ fractions passing to the small intestines. In addition, sampling from the omasum and duodenum resulted in dif- 
ferences for ruminal outflow and the site of digestion as well as the digestibility of some nutrients, particularly $\mathrm{N}$ fractions and starch. A sizable portion of this variation was associated with deviations from the assumed ideal behavior of digesta markers and difficulties encountered when attempting to obtain samples that are representative of true digesta (i.e., particle segregation or enrichment). These limitations emphasize the need to implement precautionary measures (e.g., frequent sampling throughout the feeding cycle) when measuring the passage of digesta to the omasum or duodenum.

Collectively, outcomes from this study indicate that more research will be required to determine the accuracy of nutrient flows measured at the omasal canal and duodenum and the agreement between measurements at both sites when different diets and feeding systems are used. Furthermore, published data for the flow into the omasal canal of several nutrients are limited (e.g., starch) or nil (e.g., fatty acids). In the meantime, caution is recommended when extrapolating or interpreting the underlying biology of published results as well as the outcomes from their application (e.g., model parameters and predictions).

\section{REFERENCES}

Ahvenjärvi, S., B. Skiba, and P. Huhtanen. 2001. Effect of heterogeneous digesta chemical composition on the accuracy of measurements of fiber flow in dairy cows. J. Anim. Sci. 79:1611-1620.

Ahvenjärvi, S., A. Vanhatalo, and P. Huhtanen. 2002. Supplementing barley or rapeseed meal to dairy cows fed grass-red clover silage: I. Rumen degradability and microbial flow. J. Anim. Sci. 80:2176-2187.

Ahvenjärvi, S., A. Vanhatalo, P. Huhtanen, and T. Varvikko. 2000. Determination of reticulo-rumen and whole-stomach digestion in lactating cows by omasal canal or duodenal sampling. Br. J. Nutr. 83:67-77.

AOAC. 1990. Official Methods of Analysis. 15th ed. Association of Official Analytical Chemists, Arlington, VA.

Balcells, J., J. A. Guada, J. M. Peiro, and D. S. Parker. 1992. Simultaneous determination of allantoin and oxypurines in biological fluids by high-performance liquid chromatography. J. Chromatogr. 575:153-157.

Bates, D. B., J. A. Gillett, S. A. Barao, and W. G. Bergen. 1985. The effect of specific growth rate and stage of growth on nucleic acidprotein values of pure cultures and mixed ruminal bacteria. J. Anim. Sci. 61:713-724.

Carro, M. D., and E. L. Miller. 2002. Comparison of microbial markers $\left({ }^{15} \mathrm{~N}\right.$ and purine bases) and bacterial isolates for the estimation of rumen microbial protein synthesis. Anim. Sci. 75:315-321.

Carro, M. D., and E. L. Miller. 1999. Effect of supplementing a fibre basal diet with different nitrogen forms on ruminal fermentation and microbial growth in an in vitro semi-continuous culture system (RUSITEC). Br. J. Nutr. 82:149-157.

Church, D. C. 1971. Digestive physiology and nutrition of ruminants. Vol. 1. D. C. Church, ed. OSU Bookstores, Corvallis, OR.

Craig, W. M., D. R. Brown, G. A. Broderick, and D. B. Ricker. 1987. Post-prandial compositional changes of fluid- and particle-associated ruminal microorganisms. J. Anim. Sci. 65:1042-1048.

Dehority, B. A., and C. G. Orpin. 1988. Development of and natural fluctuations in rumen microbial populations. Page 151 in The Rumen Microbial Ecosystem. P. N. Hobson, ed. Elsevier Applied Science, New York, NY.
Faichney, G. 1993. Digesta flow. Page 53 in Quantitative Aspects of Ruminant Digestion and Metabolism. J. Forbes and J. France, ed. CAB International, Wallingford, UK.

Faichney, G. J. 1980. The use of markers to measure digesta flow from the stomach of sheep fed once daily. J. Agric. Sci. (Camb.) 94:313-318.

Faichney, G. J., C. Poncet, B. Lassalas, J. P. Jouany, L. Millet, J. Doré, and A. G. Brownlee. 1997. Effect of concentrates in a hay diet on the contribution of anaerobic fungi, protozoa, and bacteria to nitrogen in rumen and duodenal digesta in sheep. Anim. Feed Sci. Technol. 64:193-213.

Firkins, J. L., M. S. Allen, B. S. Oldick, and N. R. St-Pierre. 1998. Modeling ruminal digestibility of carbohydrates and microbial protein flow to the duodenum. J. Dairy Sci. 81:3350-3369.

France, J., and R. C. Siddons. 1986. Determination of digesta flow by continuous marker infusion. J. Theor. Biol. 121:105-120.

Grovum, W. L., and V. J. Williams. 1973. Rate of passage of digesta in sheep. 3. Differential rates of passage of water and dry matter from the reticulo-rumen, abomasum and caecum and proximal colon. Br. J. Nutr. 30:231-240.

Harmon, D. L., and C. J. Richards. 1997. Considerations for gastrointestinal cannulations in ruminants. J. Anim. Sci. 75:2248-2255.

Hintz, R. W., D. R. Mertens, and K. A. Albrecht. 1995. Effects of sodium sulfite on recovery and composition of detergent fiber and lignin. J. AOAC 78:16-22.

Hooper, A. P., and J. G. Welch. 1985. Effects of particle size and forage composition on functional specific gravity. J. Dairy Sci. 68:1181-1188.

Hristov, A. N., and G. A. Broderick. 1996. Synthesis of microbial protein in ruminally cannulated cows fed alfalfa silage, alfalfa hay, or corn silage. J. Dairy Sci. 79:1627-1637.

Hristov, A. N., T. A. McAllister, D. R. Ouellet, and G. A. Broderick. 2005. Comparison of purines and nitrogen-15 as microbial flow markers in beef heifers fed barley- or corn-based diets. Can. J. Anim. Sci. 85:211-222.

Huhtanen, P., P. G. Brotz, and L. D. Satter. 1997. Omasal sampling technique for assessing fermentative digestion in the forestomach of dairy cows. J. Anim. Sci. 75:1380-1392.

Huhtanen, P., K. Kaustell, and S. Jaakkola. 1994. The use of internal markers to predict total digestibility and duodenal flow of nutrients in cattle given six different diets. Anim. Feed Sci. Technol. $48: 211-227$

Ipharraguerre, I. R., and J. H. Clark. 2005. Impacts of the source and amount of crude protein on the intestinal supply of nitrogen fractions and performance of dairy cows. J. Dairy Sci. 88:E22E37.

Karnati, S. K. R., J. T. Sylvester, Z. Yu, N. R. St-Pierre, and J. L. Firkins. 2005. Detecting changes in bacterial and protozoal populations in ruminal and omasal samples from cows fed supplemental methionine. Page 13 in Conf. Gastrointestinal Function, Chicago, IL. (Abstr.)

Kartchner, R. J., and C. B. Theurer. 1981. Comparison of hydrolysis methods used in feed, digesta, and fecal starch analysis. J. Agric. Food Chem. 29:8-11.

Legay Carmier, F., and D. Bauchart. 1989. Distribution of bacteria in the rumen contents of dairy cows given a diet supplemented with soybean oil. Br. J. Nutr. 61:725-740.

Merchen, N. R. 1988. Digestion, absorption and excretion in ruminants. Pages 172-201 in The Ruminant Animal Digestive Physiology and Nutrition. D. C. Church, ed. Prentice-Hall, Englewood Cliffs, NJ.

NRC. 2001. Nutrient Requirements of Dairy Cattle. 7th rev. ed. Natl. Acad. Sci., Washington, DC.

Perez, J. F., J. Balcells, J. A. Guada, and C. Castrillo. 1996. Determination of rumen microbial-nitrogen production in sheep: A comparison of urinary purine excretion with methods using ${ }^{15} \mathrm{~N}$ and purine bases as markers of microbial-nitrogen entering the duodenum. Br. J. Nutr. 75:699-709.

Punia, B. S., J. Leibholz, and G. J. Faichney. 1989. Effects of level of intake and urea supplementation of alkali-treated straw on protozoal and bacterial nitrogen synthesis in the rumen and partition of digestion in cattle. Aust. J. Agric. Res. 39:1181-1194. 
Ramanzin, M., L. Bailoni, and G. Bittante. 1994. Solubility, waterholding capacity, and specific gravity of different concentrates. J. Dairy Sci. 77:774-781.

Reynal, S. M., and G. A. Broderick. 2005. Effect of dietary level of rumen-degraded protein on production and nitrogen metabolism in lactating dairy cows. J. Dairy Sci. 88:4045-4064.

Reynal, S. M., and G. A. Broderick. 2003. Effects of feeding dairy cows protein supplements of varying ruminal degradability. J. Dairy Sci. 86:835-843.

Reynal, S. M., G. A. Broderick, S. Ahvenjärvi, and P. Huhtanen. 2003. Effect of feeding protein supplements of differing degradability on omasal flow of microbial and undegraded protein. J. Dairy Sci. 86:1292-1305.

Reynal, S. M., G. A. Broderick, and C. Bearzi. 2005. Comparison of ${ }^{15} \mathrm{~N}$, total purines, AA profiles, and urinary excretion of purine derivatives as markers for quantifying microbial protein flow from the rumen of lactating dairy cows. J. Dairy Sci. 88:4065-4082.

Reynal, S. M., I. R. Ipharraguerre, M. Lineiro, A. F. Brito, G. A. Broderick, and J. H. Clark. 2007. Omasal flow of soluble proteins, peptides, and free amino acids in dairy cows fed diets supplemented with proteins of varying ruminal degradabilities. J. Dairy Sci. 90:1887-1903.

Reynolds, C. K., J. D. Sutton, and D. E. Beever. 1997. Effects of feeding starch to dairy cattle on nutrient availability and production. Pages 105-134 in Recent Advances in Animal Nutrition. P. C. Garnsworthy and J. Wiseman, ed. Nottingham University Press, Nottingham, UK.
Robinson, P. H., and J. J. Kennelly. 1990. Evaluation of a duodenal cannula for dairy cattle. J. Dairy Sci. 73:3146-3157.

Rodriguez, C. A., J. Gonzalez, M. R. Alvir, J. L. Repetto, C. Centeno, and F. Lamrani. 2000. Composition of bacteria harvested from the liquid and solid fractions of the rumen of sheep as influenced by feed intake. Br. J. Nutr. 84:369-376.

Ruckebusch, Y. 1988. Motility of the gastro-intestinal tract. Pages 64-107 in The Ruminant Animal: Digestive Physiology and Nutrition. D. C. Church, ed. Prentice-Hall, Englewood Cliffs, NJ.

SAS Institute. 1999. SAS System for Windows. Release 8.1. SAS Institute, Inc. Cary, NC.

Siddons, R. C., J. Paradine, D. E. Beever, and P. R. Cornell. 1985. Ytterbium acetate as a particulate-phase digesta-flow marker. Br. J. Nutr. 54:509-520.

Titgemeyer, E. C. 1997. Design and interpretation of nutrient digestion studies. J. Anim. Sci. 75:2235-2247.

Uden, P., P. E. Colucci, and S. P. J. Van. 1980. Investigation of chromium, cerium and cobalt as markers in digesta: Rate of passage studies. J. Sci. Food Agric. 31:625-632.

Van Soest, P. J. 1994. Mathematical applications: Digestibility. Pages 354-370 in Nutritional Ecology of the Ruminant. Cornell University Press, ed. Cornell University Press, Ithaca, NY.

Wenham, G., and R. S. Wyburn. 1980. A radiological investigation of the effects of cannulation on intestinal motility and digesta flow in sheep. J. Agric. Sci. (Camb.) 95:539-546.

Williams, C. H., D. J. David, and O. Iismaa. 1962. The determination of chromic oxide in faeces samples by atomic absorption spectrophotometry. J. Agric. Sci. 59:381-385. 